\title{
Green milieu: the milieu effects on sustainable development of watershed collaborations with a case study of the New York City Watershed Agreement
}

\author{
J. Hoffman \\ John Jay College of Criminal Justice of CUNY and the CUNY Doctoral \\ Program, CUNY, New York, USA
}

\begin{abstract}
Local economic development literature has directed attention to the "milieu" effects of local interactions among firms and with governments on the qualitative nature of economic development. This article introduces the concept of the green milieu: a local economic development climate that is conducive to promoting sustainable economic development and encourages a local area to succeed economically over the long run while protecting its environmental base. It argues that watershed collaborations can create such a milieu. New York City's complex watershed collaboration is analyzed for the ingredients of a green milieu and its current record reviewed for indicators of success as a green milieu. Keywords: sustainable development, local development, watershed, collaboration, environmental regulation, milieu, New York City.
\end{abstract}

\section{Introduction}

A green milieu is a local economic development climate that is conducive to sustainable economic development. The intellectual underpinnings of this concept can be found in the discussion of adaptation to change found in four economic literatures. Local development literature analyzes the role in development of learning and the local interactions among firms and with government. The literature of sustainable development discusses the means of moving towards sustainability. The environmental regulation literature reports on the effectiveness of collaborative approaches to our non-point pollution problems because collaborations engage stakeholders and consideration of their economic concerns into the protection process and thus enhance cooperation. In the 
economics of crime literature legal responsiveness theory discusses the importance of the presence of legal means to adapt to economic change to crime prevention. A green milieu would be a local economic development climate which fostered interaction among economic actors that moved the economy towards sustainable development with legal means and the promotion of equity as a development characteristic.

Watershed collaborations create information networks described as a factor of production in local development literature and have the explicit goals of environmental protection, legal compliance and are necessarily concerned with economic equity. Are Watershed collaborations creating green milieus? Examination of New York City's nine year old very complex watershed collaboration offers the opportunity to explore collaboration as a green milieu.

Section one of this paper reviews literature that contributes to the concept of a green milieu. Section two discusses what the indicators of both the existence and success of a green milieu would be. Section three examines watershed collaborations as green milieus. Section four analyses the components of New York City's Watershed Collaboration for the ingredients of green milieu. Section five reviews New York City's Collaboration outcomes for indicators of success as a green milieu. Section six summarizes the findings.

\section{Background literature}

Local economic development literature discusses the adaptive capacity of local areas as an influence on their economic lives. Within this discussion access to knowledge and learning by firms have been identified as local development variables (Krugman [1] Camagni [2] Helmsing [3]). Helmsing [3] draws on work in evolutionary economics to describe firms as learning machines rather than rather than producers of specific products. Local places which are a network local residents, workers, businesses, governments, and non-profit organization can also be described learning machines. Markusen [4] moves in this direction in her work on "sticky places." or metro areas that have been able to either persist or adapt. Her recommendation that local areas foster the health of the structure that characterizes them is essentially a recommendation to develop and maintain a learning milieu.

The sustainable development literature recognizes the interdependence of the economy and environment and argues for economic incentives that lead towards environmental sustainability. The literature also recognizes that individuals and organizations must have sufficient income to afford the requirements of environmental protection (UNEP [5], Daly [6], Hoffman [7]).

The environmental regulation literature like that of local development has become concerned with local decision makers. Collaborative agreements involving local stakeholders have been found to be more effective than top down regulation, especially in watersheds with dispersed and mobile non-point pollution sources (NRC [8], Wondolleck and Yaffe [9], Sabatier et al [10] Richter et al [11]). Watershed collaborations are increasingly common. They may be completely voluntary or combine collaboration and regulation ([10], 
Dolsak and Ostrom [12]). They are, in essence, information networks that promote communication among stakeholders with regard to both environmental and economic health.

Within the economic crime literature, legal responsiveness theory discusses the availability legal means to help people adapt to economic change, like environmental regulations, as an aspect of crime prevention (Hoffman [13]). Preventing rather than punishing pollution is a concern of sustainable development. Environmental violations are not only undesirable per se, they undermine the culture of respect for law which is important to the protection of the extensive boundaries of water supplies.

\section{Ingredients and success indicators of a green milieu}

The regulatory and crime literature suggest that cooperative networks and legal adaptive structures can prevent resistance to increased environmental requirements. Local and sustainable development literatures suggest that localities in the process of learning to shape their interdependent economic and environmental needs can be green milieus which move towards sustainability. Such a green milieu would have the following ingredients:

- Create learning networks to help economic actors adapt

- Create learning networks about and incentives for environmental sustainability

- $\quad$ Promote economic well being through legal opportunities

- Provides legal means to meet environmental requirements

- Foster cooperation and trust

How would the effectiveness of a green milieu be assessed? Drawing on a range of sources on sustainability, ([5,6], Berke and Manta [14]) five criteria are proposed:

- Environmental sustainability: Maintaining and improving the environment for current and future generations

- Economic Sustainability: Economic development that encompasses economic welfare, equity and means of resilience for future generations

- Compatibility: development compatible with environmental protection

- Legality: provision of legal means to adapt to change

- Atmosphere of cooperation and trust for future development

\section{Watershed collaborations as Green Milieus}

Watershed collaborations at least nominally have the ingredients of a green milieu. They are learning networks created to help stakeholders adapt to the requirements of water protection and to promote compliance with environmental requirements. They necessarily address the economic and equity concerns of stakeholders. They must foster cooperation and trust to be effective.

Environmental protection measures, whether formal rules or informal agreements, create cost pressures. Goodstein [15] writes that firms seeking to 
comply with environmental requirements have saved money in part because they re-examined their production processes. Participants in collaborations thus gain learning and adaptation experience, enhancing the capacity of the local area as a learning machine with potential benefits to the entire economy.

Watershed collaborations vary considerably in scope. Some are small, short term voluntary arrangements that might not have enough impact to create a green milieu. Others are complex agreements involving many stakeholders, wide areas, and formal institutions [6]. These hold promise for creating a green milieu. New York City's watershed collaboration is of the latter type and is a good candidate for analysis as green milieu

\section{New York City's Watershed Collaboration as a green milieu}

\subsection{Background of the New York City Collaboration}

Some 90 per cent of New York City's water come from its rural Catskill/Delaware (C/D) Watershed about 120 miles north of the City and west of the Hudson River. Most of the rest comes from its upstate watershed east of the Hudson River. The City's Collaboration resulted from a 1987 rule promulgated by the US Environmental Protection Agency (EPA) that decreed that all cities of over 100,000 had to filter their drinking water. The water supply in the $\mathrm{C} / \mathrm{D}$ watershed was clean enough for the City to apply for a provision in the EPA ruling that granted permission not to filter water from these reservoirs, called a filtration avoidance determination (FAD). To obtain the FAD, the City had to take steps to protect the Catskill mountain water supply and create plans to build a filtration plant for its eastern watershed (NRC [16], Galusha [17]).

A filtration plant for the C/D Watershed would have cost at least $\$ 6$ billion, so the City began to review and tighten its upstate watershed regulations. However, the local people mobilized to protest the regulations, in part due to resentment about the City's prior use of eminent domain to destroy homes and villages in order to construct the reservoirs [17]. While the City owned land near reservoirs, and some of the watershed was protected by a forever wild designation, some $74 \%$ of the watershed land was privately owned. The miles of streams and reservoir boundaries could not be effectively protected and controlled through police action. Community cooperation was necessary for effective protection [16]. The City engaged in negotiations for collaboration.

What evolved was a complex collaboration guided by a Memorandum of Agreement (MOA) including rules and regulations and benefits for participating communities. Signatories to the MOA included the U.S. EPA, the New York City Department of Environmental Protection (DEP), New York State (NYS), the NYS Departments of Health, and of Environmental Conservation, the NYS Environmental Facilities Corporation, seven counties including five containing the C/D Watershed, 49 towns including $41 \mathrm{C} / \mathrm{D}$ Watershed towns of which 34 signed as members of a coalition of Watershed towns (CWT), eleven villages of which nine are in the C/D Watershed, and five locally active non-profit organizations (CCCD 1997 [18], MOA [19]). 


\subsection{New York City's Collaboration as a green milieu}

Three aspects of the Collaboration contribute to a green milieu: tools of environmental protection, the organizations, and spending programs (Table 1).

\subsubsection{The tools of environmental protection of the Collaboration}

Three categories of tools of environmental protection exist: land purchase, direct regulations, and education. The City is buying land from willing sellers, especially in priority areas for water protection. The rules and regulations of the MOA such as stream buffers, shape economic activity. The City's funds environmental education for Watershed and City students, via local conferences and though outreach activities such as booths at county fairs (Hoffman [20]).

These tools all contribute ingredients of a green milieu (Table 1). The rules and regulations and the education programs stimulate creation of learning networks about environmental protection. Education enhances legal compliance. The land purchases provide income to local residents. Buying land from willing sellers rather than using eminent domain gained the City cooperation and trust.

\subsubsection{Organizations of the Collaboration}

The Collaboration produced new organizations. Several were created to implement the Collaboration The Watershed Protection and Partnership Council (WPPC) of all signers of the MOA was created to meet annually, hear conflicts and issue reports. Two Watershed based non- profit organizations were funded by the City to assist in the implementation of MOA and to foster economic development compatible with clean water. One, the Catskill Watershed Corporation (CWC), oversees such programs as storm water prevention and septic upgrading. It oversees a revolving loan fund and community grant program and is a locus of education programs. The second is the Watershed Agricultural Council (WAC) which oversees a voluntary whole farm program designed to enroll farmers in a voluntary whole farm plan of best management practices (BMP) for water quality. The WAC oversees a forest stewardship program and programs to support the forest and agricultural economy. Also, the City DEP established a Community Affairs Division to work with local communities on the agreement.

Local interest organizations formed during Collaboration include the Coalition of Watershed Towns (CWT), a group formed to protest the regulation still meets as a watchdog organization, and a network of environmental groups which participated in the negotiations and is still active $[18,20]$. Two other local organizations were formed during the implementation phase. One is the "Green county mountain top" group of supervisors which meets to discuss Watershed affairs in their county. Delaware County, which has about half of the county in the Watershed, funded a Watershed Affairs Office (Hoffman [21]).

These organizations are all learning networks which increase and enrich connections in the Watershed networks. When participants are government employees, they, in turn, transmit information to the business community. The CWC and WAC both work to foster economic development compatible with clean water. The WPPC brings participants together and provides a venue for the 
discussion of disputes. The CWT protests when it feels that the local communities can be damaged by some aspect of the Collaboration. The organizations of the Collaboration are engaged in activities that create a green milieu (Table 1).

Table 1: Collaboration characteristics.

\begin{tabular}{|c|c|c|c|c|c|}
\hline & $\begin{array}{l}\text { creates } \\
\text { learning } \\
\text { networks }\end{array}$ & $\begin{array}{l}\text { promotes } \\
\text { sustainablity of } \\
\text { environment }\end{array}$ & $\begin{array}{l}\text { promotes } \\
\text { economic } \\
\text { well being }\end{array}$ & $\begin{array}{l}\text { provides } \\
\text { legal } \\
\text { means }\end{array}$ & $\begin{array}{l}\text { promotes } \\
\text { cooperation } \\
\text { and trust }\end{array}$ \\
\hline \multicolumn{6}{|l|}{ Environmental Protection Tools } \\
\hline MOA Rules \& regulations & & $\mathrm{x}$ & & & \\
\hline Land Acquistion by fee simple & & $\mathrm{x}$ & $\mathrm{x}$ & & $\mathrm{x}$ \\
\hline Education $x$ & & $\mathrm{x}$ & & $\mathrm{x}$ & $\mathrm{x}$ \\
\hline \multicolumn{6}{|l|}{ Organization } \\
\hline WPPC $x$ & & $\mathrm{x}$ & & & \\
\hline DEP watershed affairs $x$ & & $\mathrm{x}$ & & & $\mathrm{x}$ \\
\hline CWC \& WAC & & $\mathrm{x}$ & $\mathrm{x}$ & & \\
\hline CWT & & & & & \\
\hline environmenatl groups $x$ & & $\mathrm{x}$ & & & \\
\hline Green mountain top group $x$ & & $\mathrm{x}$ & & & \\
\hline Delaware County Watershed Affairs & $\mathrm{x}$ & $\mathrm{x}$ & $\mathrm{x}$ & & \\
\hline \multicolumn{6}{|l|}{ Spending programs } \\
\hline \multicolumn{6}{|l|}{ Environmental protection } \\
\hline Infrastructure & & $\mathrm{x}$ & $\mathrm{x}$ & $\mathrm{x}$ & \\
\hline compliance subsidies & & $\mathrm{x}$ & & $x$ & \\
\hline Whole farm and forest stewardship & $x$ & $\mathrm{x}$ & $x$ & $x$ & $x$ \\
\hline conferences $x$ & $x$ & $\mathrm{x}$ & $x$ & $x$ & $x$ \\
\hline \multicolumn{6}{|l|}{ Economic development } \\
\hline watershed development plan & & $\mathrm{x}$ & $x$ & & \\
\hline community grants $x$ & & & $x$ & & $x$ \\
\hline revolving loan fund $x$ & $x$ & $\mathrm{x}$ & $x$ & & $x$ \\
\hline tourism and farm market promotion $x$ & $x$ & $x$ & $x$ & & \\
\hline hiring of personnel & & $\mathrm{x}$ & $x$ & & \\
\hline \multicolumn{6}{|l|}{ Cooperation } \\
\hline good neighbor program & & & $x$ & & $x$ \\
\hline tax fund & & & $x$ & & $x$ \\
\hline
\end{tabular}

\subsubsection{The spending programs of the collaboration}

Collaboration spending can be grouped into three categories: environmental protection, economic development and fostering cooperation. All contribute ingredients to a green milieu (Table 1).

Environmental protection spending comes primarily from the City but is amplified when City funds are used in local matching grants. The City spends money for direct protection and to organizations that oversee protection programs. The major category of direct spending undertaken by the City is for infrastructure such as wastewater treatment plants (WWTP) and septic systems. In addition to the funding of the $\mathrm{CWC}$, the WAC and the WPPC, the City also pays for research and assistance from Cornell University and for conservation easements to keep land in farming [21].

Spending by the City that contributes to economic development includes local hiring, the funding of a Watershed region economic development plan, a $60 \$$ million revolving loan fund, community development grants, funds to promote the tourist economy and local products, conservation easement purchases and financing for local infrastructure such as new sewer lines The CWC kept lists of 
local providers of needed services to increase the likelihoods that the spending would stimulate the local economy [21].

City spending designed to foster cooperation and trust include "no strings attached" good neighbour payments to local governments and funds to support local governments in tax disputes with New York City.

These spending programs create learning networks, environmental protection, local economic well being, and legal means for people to meet the regulations, thus helping foster cooperation and trust.

\section{Success indicators New York City's green milieu}

\subsection{Local development problems}

In order to understand the challenges faced by the Collaboration, the nature of the local economy at the beginning of the MOA must be understood. Dairy farms and forests dominated the rural, sparsely populated, mountainous landscape. Scattered hamlets and villages of the Watershed had typically been built along streams. . Much of the infrastructure was depreciated; including the area's septic tanks and wastewater treatment plants. The streams themselves had often been straightened or had deteriorated borders, and could too easily carry silt to the City's reservoirs $[16,20,21]$.

The economy had been stagnant for decades Dairy farming had experienced the loss of its supplier base. The forever wild protection of the state constitution for the Catskill Park land and steep slopes meant that much land was not available for development. Small businesses were especially vulnerable to the competition of super stores, large farms and globalization. Many jobs were low income service and retail jobs, often in the tourist industry. There was a lot of part time work. Government jobs, primarily states and local and City, provided some stability, with regular incomes with benefits to about a fifth of the population $[20,21]$.

Strict water regulations with expensive infrastructure requirements could have undermined the economy of this already run down area. However, City's need for a collaborative partnership generated a Collaboration with the ingredients of a green milieu. What are the indications of success so far?

\subsection{Environmental sustainability}

A quick summary indicator of the Collaboration's environmental success is the EPA's award of three successive FAD's, continuing permission not to filter the water. A supplemental indicator is absence of incidents of water borne disease attributed to Watershed water (NYC [22]). Specific gains are many. The City has upgraded its own watershed waste water treatment plants to tertiary level treatment and has upgraded enough of the WWTP's in the C/D Watershed to protect $97 \%$ of the Watershed's effluent. It has restored wetlands and returned the meander to streams to prevent flooding. The City monitors and has replacement plans for local dams. Upgrades of 2000 septic systems are completed, and funds for their maintenance are committed. The voluntary whole farm program has participation by $95 \%$ of commercial farmers. City land purchases have tripled its watershed holdings, and it has a long run planting 
program to maintain the forested land's capacity to cleanse water. Finally phosphorous restrictions on the Cannonsville reservoir were lifted (NYC [23]). The creation of phosphorous restriction program to guide economic development by the Watershed Affairs Office of Delaware county promises will help keep that reservoir clean [21].

\subsection{Economic sustainability: development, well being compatibility}

A variety of indicators point to milieu successes in enhancing development and economic welfare in the Watershed. Studies of residents during the early years of the collaboration (1990-2000) found that Watershed residents, while having relatively low income and high unemployment for the region, had experienced greater improvements in median income, wage and salary growth and self employment income than control areas used in the study Also unemployment had declined more and inequity increased less than control areas [20]. A similarly controlled study of employers found a growth in both units of business and employment from 1997-2003, and that the Watershed had growth even when control areas experiencing a down turn. A negative economic result for the period was the relatively low wage growth. While the wage growth cannot be attributed to the Collaboration, milieu effects failed to overcome the factors such as international competition and location disadvantages that held wages down. [21]. Another problem not overcome by the milieu is the pressure put on property taxes of low income residents resulting from expensive home construction by higher income second home owners [20].

Long run economic stability was promoted by various milieu programs. Loans to wood working businesses support secondary markets for holders of forest land. Purchases of conservation easements help to keep land in farming. Economic diversity, which provides stability, has been aided by loans to small to medium size manufacturers, which helped stabilize them. Links to New York City customers helped farmers diversify into growing products for that market. Also, internet based businesses have opened in the Watershed in part with the help of the loan programs or local government programs inspired by the need to promote businesses compatible with water quality [21].

Compatibility of economic activity and water quality has been enhanced. Improved environmental infrastructure "cleanses" all Watershed activities. The service industry, not a major polluter, is the major source of job growth. Local officials have promoted non-polluting e- business by such means as such as subsidizing web pages and creating e-business incubators. Delaware County has a phosphorous reduction plan to guide economic activity in its part of the Watershed [21]. The voluntary farm program's best management practices protects water quality and kept farm pollutants from the water in a recent flood (Rauter interview [24]).

\subsection{Legality, cooperation and trust}

The legal means to abide by regulations provided to by the Collaboration have been used. Local residents have used the septic grant program and reported their septic problems. Businesses and local communities have used the loan and grant 
programs to improve environmental infrastructure [20,21]. The WPPC's forum for dispute resolution is credited with the avoidance of law suits about development on steep slopes (Harding interview [25]).

Use of conflict procedures is evidence of flexibility in the structure of the Collaboration which enhances long run cooperation. The City responded to local protest and redesigned its Watershed signs. The WPPC has provided a forum for disputes about recreation rules as well as slopes. The tax fund has been used by local areas to stand up to the City on tax issues. Evidence that the periodic need to renew FAD's enhances cooperation is provided by the City's agreement to pay for maintenance septic tanks during one set of negotiations [20,21,23].

The many successes of the milieu have been accompanied by problems beyond those already mentioned. Local residents protested watershed police issuing traffic tickets and controversy abounds about the City's reluctance to grant a permit to a proposed mountain top golf course. There are also worries that the land acquisition program will ruin the area for tourism.

\section{Summary}

There are problems in this Collaboration. Some are rooted in national and international forces and should lead Collaboration officials to lobby higher levels of government for such things as affordable housing. Others problems are amenable to local control. Some of the latter such as signage have been attended to, while others are still contributing to the learning experience of a Collaboration. On balance, the successes of Collaboration a green milieu are remarkable. The Watershed economy is healthier and more compatible with preservation of water quality than before the Collaboration began. The approach of this Collaboration in considering the economic needs of the local area and providing forums for discussion provides a model that should be studied by others, especially those with transboundary water supplies and water sources in poor communities.

\section{References}

[1] Krugman, P. What's new about the new economic geography. Oxford Review of Economic Policy 14 (2) pp 151-66 (1998).

[2] Camagni, R. Local Milieu, uncertainty and innovation networks: towards a new dynamic theory of economic space in R. Camagni (ed.) Innovation Networks: spatial Perspectives pp. 121-45. London: Belhaven Press. 1991.

[3] Helmsing A.H. J. (Bert). Externalities, learning and governance: new perspectives on local economic development. In development and change vol.32 pp 277-308. (2001).

[4] Markusen, A. Sticky places in slippery space: a typology of industrial districts. Economic Geography, 72(3) 293-313. 1996.

[5] (UNEP) United Nations Environment Program. Our common future. Report of the world commission on environment and development. New York: United Nations. 1987.

[6] Daly H. E. and Cobb, J. B. Jr. 1994. For the Common Good. Boston: Beacon Press. 1994, p 462-4 
[7] Hoffman, J. Economic Stratification and Management of Water Quality: New York City's Catskill/Delaware Watershed. Environmental Values. 14, 447-470. 2005.

[8] (NRC) National Research Council. New Strategies for America's Water Supply. Washington, D.C.: National Academy Press. 1999.

[9] Wondolleck, Julia M and Yaffee, Steven L. Making Collaboration Work. Washington D.C.: Island Press. 2000

[10] Sabatier, P. Focht, W. Lubell M., Trachterberg, Z Vedlitz, A. and Matlock, M. Swimming Upstream: Collaborative Approaches to Watershed Management. Cambridge, MA: MIT Press. 2005.

[11] Richter, Brian D. Mathews, Ruth, Harrision David L. and Wigington, Robert. Ecologically Sustainable Water Management: Managing River Flows for Ecological Integrity. Ecological Applications, 13(1), 206-24. 2003.

[12] Dolsak, N. and Ostrom E. (Eds.). The Commons in the New Millennium: Challenges and Adaptations. Cambridge: Mass.: MIT Press, 2003.

[13] Hoffman, J. "Legal responsiveness: a contribution to a structural theory of economic crime." International Journal of Social Economics. Vol 30 (3) pp. 255-274. 2002.

[14] Berke, P. and Manta, M. Are We Planning for Sustainable Development? An Evaluation of 30 Comprehensive Plans. Journal of The American Planning Association 66 (1):21-32. 2000

[15] Goodstein Eban. The Trade Off Myth. Fact and Fiction about Jobs and the Environment. Covelo California: Island Press. 1999

[16] (NRC) Nation Research Council. Watershed Management for Potable Water Supply. Washington, D.C. National Academy Press. 2000.

[17] Galusha, D. Liquid Assets. A History of New York City's Water System. Fleishman's New York: Purple Mountain Press. 1999.

[18] (CCCD) The Catskill Center for Conservation and Development. Summary Guide to the Terms of the Watershed Agreement. Arkville, NY: The Catskill Center for Conservation and Development. 1997

[19] (MOA) Memorandum of Agreement $1997 \mathrm{http} / / / \mathrm{www} . n y s e f c . o r g / t a s /$ MOA/MOAPg1.htm

[20] Hoffman, J Census Peek: Collaboration in the New York City Catskill/Delaware Watershed: Case Study 1990-2000. Environment, Development and Sustainability July 2006

[21] Hoffman, J. Watershed Shifts: Case Study of Employers in the Catskill/Delaware watershed 1990-2003 (manuscript under review).

[22] New York City. Waterborne Disease Risk Assessment Program Annual Report. http://www.nyc.gov/html/dep/html/wdrap.html. 2005

[23] (NYCDEP) New York City Department of Environmental Protection. 2005 Water Quality Report http://www.nyc.gov/html/dep/pdf/ wsstat05.pdf 2005.

[24] Interview with Karen Rauter Communications Director of the WAC. September 2006.

[25] Interview with Bill Harding, Director of the WPPC. March 2006. 